\title{
The use of social media in the B2B sales process: a meta synthesis
}

\author{
Graziela Perretto Rodrigues, Adriana Roseli Wünsch Takahashi and \\ Paulo Henrique Muller Henrique Prado \\ Departamento de Administração Gerale Aplicada, \\ Universidade Federal do Paraná, Curitiba, Brazil
}

\begin{abstract}
Purpose - The purpose of this study is to understand how business-to-business organizations use social media during the sales process.

Design/methodology/approach - The meta-synthesis steps methodology (Hoon, 2013) was applied.

Findings - This study presents a theoretical framework and contributes to improved understanding of how business can use social media in the sales process stages. The results allow identifying stages, discussing the integration between marketing and sales and generating benefits for the organization.

Originality/value - The proposed framework helps in understanding the previously performed fragmented studies. This study shows that social media use not only influences the sales process stages and increases the benefits to the business but also works as a mediator in the relation between sales process stages and identified benefits.
\end{abstract}

Keywords Meta-synthesis, Social media, Sales process, Business-to-business

Paper type Research paper

\section{Introduction}

Social media is a technology that has been acquiring importance in our daily personal and business lives. It has changed the business scenario because it has offered

(C) Graziela Perretto Rodrigues, Adriana Roseli Wünsch Takahashi and Paulo Henrique Muller Henrique Prado. Published in RAUSP Management Journal. Published by Emerald Publishing Limited. This article is published under the Creative Commons Attribution (CC BY 4.0) license. Anyone may reproduce, distribute, translate and create derivative works of this article (for both commercial and non-commercial purposes), subject to full attribution to the original publication and authors. The full terms of this license may be seen at http://creativecommons.org/licences/by/4.0/ legalcode

The authors contributed in the following ways to the paper: Perretto Rodrigues, Graziela Perretto, Corresponding Author, Conceptualization (Lead), Formal analysis (Lead), Investigation (Lead), Methodology (Lead), Project administration (Lead), Resources (Lead), Supervision (Lead), Validation (Lead), Visualization (Lead), Writing-original draft (Lead), Writing-review \& editing (Lead), Takahashi, Adriana Roseli Wünsch, Conceptualization (Lead), Formal analysis (Supporting), Investigation (Supporting), Methodology (Lead), Project administration (Supporting), Resources (Lead), Supervision (Supporting), Validation (Supporting), Visualization (Supporting), Writing-original draft (Supporting), Writing-review \& editing (Supporting), Prado, Paulo Henrique Muller Henrique, Conceptualization (Lead), Formal analysis (Supporting), Investigation (Supporting), Methodology (Supporting), Project administration (Supporting), Resources (Supporting), Supervision (Supporting), Validation (Supporting), Visualization (Supporting), Writing-original draft (Supporting), Writing-review \& editing (Supporting).

Received 18 February 2019 Revised 6 June 2019 22 July 2019

7 August 2019

Accepted 16 October 2019 
RAUSP

56,1

organizations a chance to communicate with clients in a more effective manner (Rapp, Beitelspacher, Grewal, \& Hughes, 2013). Social media usage has been a discussion theme for academics and for professionals because it benefits business growth (Lashgari, Sutton-Brady, Solberg Søilen, \& Ulfvengren, 2018). More research is required, however, to investigate its use by the sales force (Itani, Agnihotri, \& Dingus, 2017).

Gradually, business is becoming aware of the importance of social media usage for client relations and communication (Rodriguez, Peterson, \& Krishnan, 2012), in addition to its use as a platform for realizing online campaigns in which marketing actions are performed (Khang, Ki, \& Ye, 2012). Despite its relevance, there is no understanding of its impact on organizational activities and how activities performed in the media influence the sales process, thereby generating benefits for the organization.

Businesses sell products and services in a market that has become more competitive. Moreover, a consumer is more careful in his purchase decision-making process because of the considerable amount of available information. Based on these facts, businesses should use new technology to enhance the sales process (Rodriguez, Ajjan, \& Peterson, 2016) and allow information exchange with clients (Marshall, Moncrief, Rudd, \& Lee, 2012).

Recently, as can be seen in the literature review, studies have investigated the impact of social media on the sales process (Andzulis, Panagopoulos, \& Rapp, 2012) in studies that are related to social media use, sales capability and performance (Rodriguez et al., 2012; Rodriguez et al., 2016), as well as in studies that focus on social media use as a tool for customer relationship management (CRM) (Trainor, Andzulis, Rapp, \& Agnihotri, 2014). In these studies, there is a consensus that social media helps in the sales process and generates performance. They show some converging aspects by the existence of a relation between the use of social media and sales (Rodriguez et al., 2016).

Other studies have been about social media use and product sales for consumers (B2C). Companies that operate business to business (B2B) have started to explore social media, although there is no understanding of whether its adoption favors sales (Brink, 2017; Siamagka, Christodoulides, Michaelidou, \& Valvi, 2015) or its organizational implications (Ngai, Moon, Lam, Chin, \& Tao, 2015). B2B companies have a sales process with a larger number of stages that demands considerable effort to build and maintain customer relationships using communication-related tools such as social media (Chang, 2014; Rodriguez et al., 2012).

From the need to understand social media use in B2B negotiations and the lacunas identified in the literature, this meta synthesis aims to answer the following research question:

$R Q 1$. How has social media been used by B2B organizations in the sales process?

To achieve this objective, the meta-synthesis methodology proposed by Hoon (2013) has been applied. It allows the understanding of how companies use social media in the sales process in an exploratory and inductive way since it seeks the information synthesis already addressed in case study qualitative research. Thus, it is possible to gather information to build the theory and subsequently present a theoretical pattern with concepts and new perspectives, thereby contributing to the already existent theory. This study presents the concepts of social media use, sales in B2B organizations, methodology, the results and final considerations. 


\section{Social media use}

New technologies arise and consolidate themselves in the market as social media, thus influencing the way business is performed. There is a requirement to identify emerging technologies and know-how to operationalize them to be able to add value to organizational activities (Marshall et al., 2012). Social media comprises applications that use the Internet as support and allow creation, sharing and content exchanges by users e.g. YouTube and Facebook (Kaplan \& Haenlein, 2010).

Social media helps professionals from marketing and sales areas. Both areas use this media to help communicate not only with prospects and clients but also with other stakeholders (Rodriguez et al., 2012). Social media allows sharing of content online, facilitating social interaction and developing online networks (Agnihotri, Kothandaraman, Kashyap, \& Singh, 2012).

There is a tendency to use social media to help communicate with clients and to facilitate sales (Itani et al., 2017). Social media use is not sufficient; it is necessary to understand its application in the sales process, which comprises distinct activities. The efforts of those who manage the sales force and support the salespeople are included in these activities (Guenzi, Sajtos, \& Troilo, 2016). This management aims to guide team efforts to the correct usage of tools. Managers need to define how much to invest in social media. They ought to understand how social media can be used in practice to support sales activities and engender a relationship with clients (Trainor et al., 2014).

Some studies show that social media use is valuable to improve sales (Marshall et al., 2012), and its use contributes to organizational results (Rodriguez et al., 2012). Moreover, to establish the relationship between the business and consumers and in B2B negotiations, social media use and sales activities are important (Rapp et al., 2013). Social media use is a strategy that can be applied in B2B (Siamagka et al., 2015) contexts to understand and develop customer relationships (Chang, 2014).

\section{Sales in business to business organizations}

$\mathrm{B} 2 \mathrm{~B}$ organizations usually have fewer customers and need to manage the relationship using information technology systems (Chang, 2014). However, the adoption and implementation of new technologies is a challenge because of the complexity of the B2B sales process, which has a greater number of stages (Agnihotri, Dingus, Hu, \& Krush, 2016; Rodriguez et al., 2012; Siamagka et al., 2015).

A sale starts with the acquisition of clients in the market and comprises activities arranged into different stages. D'Haen and Van den Poel (2013) proposed a framework that divided the sales process into different stages related to the purchase funnel. The first stage is the prospection of new potential clients (suspects). Second, the qualification of these suspects according to the criteria defined by the business (prospects). Third, contact is made with the prospects who are prepared to become an opportunity (qualified leads). Lastly, qualified leads are prepared to become real business opportunities. In this framework, the authors did not mention the post-sale stage, which involves tasks that aim to enhance client satisfaction and loyalty (Dombrowski \& Malorny, 2016) because the model focuses on client acquisition.

Andzulis et al. (2012) cited the sales process stages and included follow-up activities after sales closing. The stages are client acquisition, approach, understanding client requirements, business opportunities, solution presentation, closing sales and the final client follow-up.

Use of social media 
RAUSP

56,1

\section{2}

\section{Methodology}

The eight-step meta-synthesis methodology by Hoon (2013) was applied in this study (Table 1).

For case selection, the following keywords were searched: "social media" AND "sales*". The parameter - * - was used because of the need to search for words related to sales, such as sales process and salesperson, because it is the salesperson who performs the sales activities that uses social media. The databases used were Web of Knowledge and ProQuest. For a more assertive selection, filters were selected: "title, abstract and keywords", "article", in the area of "applied social science and business" in the last five years of publication. 173 study papers were then identified in the search on Web of Knowledge and 127 in ProQuest. A total of 261 study papers were found because some of them were in both databases. These studies were published in 133

\begin{tabular}{|c|c|c|c|}
\hline Meta-Synthesis steps & Analytical objective & $\begin{array}{l}\text { Strategy or analytical } \\
\text { procedure used }\end{array}$ & $\begin{array}{l}\text { Result that generated a theoretical } \\
\text { contribution }\end{array}$ \\
\hline $\begin{array}{l}1 \text { Research question } \\
\text { development }\end{array}$ & $\begin{array}{l}\text { Readings about the } \\
\text { proposed theme to } \\
\text { identify a theoretical } \\
\text { lacuna }\end{array}$ & $\begin{array}{l}\text { The initial search for } \\
\text { articles in the database }\end{array}$ & $\begin{array}{l}\text { Theoretical lacuna identification } \\
\text { and research question development }\end{array}$ \\
\hline $\begin{array}{l}2 \text { Discovery of } \\
\text { relevant research }\end{array}$ & $\begin{array}{l}\text { Relevant publication } \\
\text { identification in the } \\
\text { database }\end{array}$ & $\begin{array}{l}\text { Research for the } \\
\text { keywords "social media" } \\
\text { and "sales" in the Web } \\
\text { of Knowledge and } \\
\text { ProQuest }\end{array}$ & $\begin{array}{l}\text { Sample of } 261 \text { articles, among } \\
\text { them } 25 \text { case studies }\end{array}$ \\
\hline $\begin{array}{l}3 \text { Inclusion and } \\
\text { exclusion criteria }\end{array}$ & $\begin{array}{l}\text { Establish inclusion } \\
\text { and exclusion criteria } \\
\text { from selected articles }\end{array}$ & $\begin{array}{l}\text { Abstract reading to } \\
\text { criteria identification. } \\
\text { Reading of } 25 \text { case } \\
\text { studies }\end{array}$ & Selection of seven studies \\
\hline $\begin{array}{l}4 \text { Data extraction and } \\
\text { data coding }\end{array}$ & $\begin{array}{l}\text { Codify the } \\
\text { characteristics of the } \\
\text { selected research } \\
\text { papers and identify } \\
\text { insights }\end{array}$ & $\begin{array}{l}\text { Research paper detailed } \\
\text { reading to tabulate the } \\
\text { information and } \\
\text { insights }\end{array}$ & $\begin{array}{l}\text { Data organization and the } \\
\text { elaboration of a table with coding }\end{array}$ \\
\hline $\begin{array}{l}5 \text { Case-specific level } \\
\text { analysis }\end{array}$ & $\begin{array}{l}\text { Identification and } \\
\text { analysis of variables: } \\
\text { social media and } \\
\text { sales process }\end{array}$ & $\begin{array}{l}\text { Casual links } \\
\text { identification among } \\
\text { variables }\end{array}$ & $\begin{array}{l}\text { Themes, concepts and pattern } \\
\text { identification }\end{array}$ \\
\hline $\begin{array}{l}6 \text { Synthesis on a } \\
\text { transversal level }\end{array}$ & $\begin{array}{l}\text { Matching of specific } \\
\text { causal links of each } \\
\text { case in a net aiming } \\
\text { for the generation of a } \\
\text { pattern among the } \\
\text { variables }\end{array}$ & $\begin{array}{l}\text { Study variables } \\
\text { classification and } \\
\text { presentation of the } \\
\text { relationship found } \\
\text { among the cases }\end{array}$ & $\begin{array}{l}\text { Pattern and model identification } \\
\text { with the study variables, which are } \\
\text { classified to guarantee research } \\
\text { validity }\end{array}$ \\
\hline $\begin{array}{l}7 \text { Theory } \\
\text { construction from } \\
\text { meta synthesis } \\
\text { information }\end{array}$ & $\begin{array}{l}\text { Identification of } \\
\text { social media uses in } \\
\text { different stages of the } \\
\text { sales process as the } \\
\text { two of them together } \\
\text { generate benefits }\end{array}$ & $\begin{array}{l}\text { The results were } \\
\text { grouped according to } \\
\text { their theoretical } \\
\text { relevance }\end{array}$ & $\begin{array}{l}\text { Theoretical framework proposal } \\
\text { and research propositions, which } \\
\text { show the concepts and the relation } \\
\text { among them }\end{array}$ \\
\hline 8 Discussion & $\begin{array}{l}\text { Results, limitations } \\
\text { and future research } \\
\text { discussion }\end{array}$ & $\begin{array}{l}\text { Rigor, reliability and } \\
\text { validity of results }\end{array}$ & $\begin{array}{l}\text { Validity legitimacy and procedure } \\
\text { usage reliability }\end{array}$ \\
\hline
\end{tabular}

Source: Adapted from Hoon (2013)
Table 1.

Meta synthesis protocol 
journals. The main journals were Industrial Marketing Management, Journal of Advertising Research, Journal of Business \& Industrial Marketing, Journal of Marketing, Journal of Marketing Research and Journal of Research in Interactive Marketing, all of which had eight studies. Both the media Journal of Personal Selling \& Sales Management and the Journal of Retailing and Consumer Service had six studies. The others had five or fewer publications.

In the third step, 25 studies were selected for the meta-synthesis with the case study. A complete reading of the 25 studies was performed to verify if they were in the investigation scope. This eliminated another 18 studies (Table 2).

\begin{tabular}{ll}
\hline Criteria & Justification \\
\hline $\begin{array}{l}\text { 1 Qualitative Case } \\
\text { Study }\end{array}$ & $\begin{array}{l}\text { The exclusion of studies } \\
\text { that neither had a } \\
\text { qualitative approach nor } \\
\text { used the case study } \\
\text { methodology }\end{array}$ \\
$\begin{array}{l}\text { 2 Conceptual Models } \\
\text { and Literature }\end{array}$ & $\begin{array}{l}\text { Although considered } \\
\text { Reviews }\end{array}$ \\
$\begin{array}{l}\text { development, theoretical } \\
\text { study papers do not fulfill } \\
\text { the objective to use the } \\
\text { primary data found in the } \\
\text { empirical studies }\end{array}$
\end{tabular}

References and Exclusion Reasons

186 quantitative studies were removed: 2 studies that used secondary data; 2 meta-analysis; 5 studies with mixed-methodology; 1 used grounded theory; 1 did a comparative analysis; 1 used action research; 1 did a discourse analysis; 7 studies used content analysis

Albers, Raman, and Lee (2015), Batra and Keller (2016), Bolos, Idemudia, Mai, Rasinghani, and Smith (2016), Chen and Gao (2019), Drechsler and Weißschädel (2018), Flaherty et al. (2018), Habibi, Hamilton, Valos, and Callaghan (2015), Hofacker, Malthouse, and Sultan (2016), Lin, Swarna, and Bruning (2017), Lindsey-Mullikin and Borin (2017), Marolt, Pucihar, and Zimmermann (2015), Ioanid, Militaru and Mihai (2015), Moncrief (2017), Moncrief, Marshall, and Rudd (2015), Nunan, Sibai, Schivinski, and Christodoulides (2018), Oh (2017), Orozco (2016), Papp-Vary (2015), Rane, Mulla, Sarguru, and Sayed (2017), Roch and Mosconi (2016), Rodriguez et al. (2016), Spragg (2017), Thorat, Deshpande, and Shaga (2017), Zhao and Balagué (2015)

3 Studies not Studies that were not in Accessible for search English and not available 5 studies not available for download and 1 in Arabic for download

4 Adequate Scope to Only studies in which the Research Question scope aligned with the research question were considered

Brink (2017) focuses only on social media use. Mahapatra Ramani, and Kulkarni (2019) focus on the B2B market but does not mention social media use and sales process. Annett-Hitchcock and Xu (2015), Arriaga, Andreu Domingo, and Berlanga Silvente (2017), Bohlin, Shaikh, and Hanafizadeh (2018), de Brito Silva, Santana, and da Costa (2018), Garner, Goldberg, and Pou (2017), Gilfoil, Aukers, and Jobs (2015), Jones, Borgman, and Ulusoy (2015), Kim, Dwivedi, Zhang, and Jeong (2016), Mirza (2014), Nicoli and Papadopoulou (2017), Shemi and Procter (2018), Valos, Haji Habibi, Casidy, Driesener, and Maplestone (2016) are B2C studies. Mauroner (2016) investigates social media impact in the creative process and Sanakulov et al. (2018) verify how salespeople use social media

Table 2.

Inclusion and exclusion criteria

Source: Adapted from Hoon (2013) 
RAUSP

56,1
The selected studies for the meta-synthesis are listed in Table 3. It can be observed that six of them were published in journals A1 (H Index $>24)$ and one classified as A2 $(24<=\mathrm{H}$ Index $<$ 9) according to the QUALIS from CAPES criteria, which indicates high-impact journals.

Table 4 shows the coding and extraction of data. The final guide had 42 items.

\section{4}

\section{Data analysis}

After data coding, seven selected articles were analyzed, and a transversal level synthesis was realized. It was possible to suggest a theoretical framework and present research propositions with this data.

\begin{tabular}{|c|c|c|c|}
\hline Author(s) (year) & Title & Journal & $\begin{array}{l}\mathrm{SJR}^{*}(\mathrm{H} \\
\text { index }\end{array}$ \\
\hline $\begin{array}{l}\text { Andersson and } \\
\text { Wikström (2017) }\end{array}$ & $\begin{array}{l}\text { Why and how are social media used in a B2B } \\
\text { context, and which stakeholders are involved? }\end{array}$ & $\begin{array}{l}\text { Journal of Business \& } \\
\text { Industrial Marketing }\end{array}$ & 55 \\
\hline $\begin{array}{l}\text { Bocconcelli et al. } \\
\text { (2017) }\end{array}$ & Social media as a resource in SMEs' sales processes & $\begin{array}{l}\text { Journal of Business \& } \\
\text { Industrial Marketing }\end{array}$ & 55 \\
\hline Cron (2017) & Macro sales force research & $\begin{array}{l}\text { Journal of Personal Selling } \\
\& \text { Sales Management }\end{array}$ & 55 \\
\hline $\begin{array}{l}\text { Järvinen and } \\
\text { Taiminen (2016) }\end{array}$ & $\begin{array}{l}\text { Harnessing marketing automation for B2B content } \\
\text { marketing }\end{array}$ & $\begin{array}{l}\text { Industrial Marketing } \\
\text { Management }\end{array}$ & 106 \\
\hline $\begin{array}{l}\text { Karjaluoto et al. } \\
\text { (2015) }\end{array}$ & $\begin{array}{l}\text { The role of digital channels in industrial marketing } \\
\text { communications }\end{array}$ & $\begin{array}{l}\text { Journal of Business \& } \\
\text { Industrial Marketing }\end{array}$ & 55 \\
\hline $\begin{array}{l}\text { Lashgari et al. } \\
\text { (2018) }\end{array}$ & $\begin{array}{l}\text { Adoption strategies of social media in B2B firms: a } \\
\text { multiple case study approach }\end{array}$ & $\begin{array}{l}\text { Journal of Business \& } \\
\text { Industrial Marketing }\end{array}$ & 55 \\
\hline Lipiäinen (2015) & $\begin{array}{l}\text { CRM in the digital age: Implementation of CRM in } \\
\text { three contemporary B2B firms }\end{array}$ & $\begin{array}{l}\text { Journal of Systems and } \\
\text { Information Technology }\end{array}$ & 17 \\
\hline
\end{tabular}

Table 3. Articles
Notes: SJR - Scimago Journal \& Country Rank. Retrieved on July 29, 2019 from Retrieved from www. scimagojr.com/

Source: The authors (2019)
Table 4.

Coding and extraction data criteria
Items detailing

Author(s), title, journal, year, and kind of study

Objectives, survey questions, and theoretical contributions

What are the Authors'

Intentions?

Theoretical Framework

Context Definition

Methodology

Techniques and Data

Collection Sources

Data Analysis

What are the Insights?

Discussion

General Evaluation

How social media use and sales process are conceptualized. How the study discusses the relation between the concepts in the B2B business Country, industry/sector, context, local and research alignment Research design, approach, analysis unit, number of cases, and sampling strategy

Data collection techniques, source and data management

Methods and data analysis techniques

Main results and insights

Findings discussion, theoretical/managerial contributions, and limitations

Relevance evaluation and research reliability

Source: Adapted from Hoon (2013) 
To be able to develop this meta-synthesis from each selected case study, the causal relations between the variables (social media use and sales process) were confirmed. A theoretical framework was elaborated from the synthesis information of each case (Figure 1).

This framework gathers the main results of each analyzed study. Social media use encompasses the development of content to be published in social media (Lashgari et al., 2018). Other already consolidated tools in marketing and sales, such as CRM, continue to be used by companies. Because of the influence of social media, it is suggested that CRM be media used along with social media (Cron, 2017) and thus it is presented as a social CRM concept (Lipiäinen, 2015). It is suggested that a company use social media in conjunction with the content marketing technique (material and text creation) published in different online media and with the support of other available tools. These technologies influence the sales process (Bocconcelli, Cioppi, \& Pagano, 2017; Järvinen \& Taiminen, 2016; Karjaluoto, Mustonen \& Ulkuniemi, 2015); however, they are modified when used because social media use and sales process stages suffer each other's influence. Finally, social media use in the sales process stages generates benefits for the organization (Andersson \& Wikström, 2017; Bocconcelli et al., 2017; Karjaluoto et al., 2015; Lipiäinen, 2015).

The proposed framework shows that the functional marketing and sales areas should be integrated (Andersson \& Wikström, 2017; Bocconcelli et al., 2017) because the stages that form the process have activities in both areas. However, closing sales is a task with commercial intent and is directly realized with clients. In the B2B context, clients perform repetitive purchases, and the focus in this market is to create loyal relationships (Chang, 2014); therefore, clients that have gone through the post-sales stage can become potential clients again, i.e. prospects or leads. Because of the small number of clients, they end up purchasing again from the supplier, which strengthens the necessity to include a post-sales step.

The detail on how these presented relationships were identified is displayed in the following topics.

\section{Transversal level study synthesis}

The transversal analysis aimed to show the relation between the variables (meta-causal). A mapping was done, which was displayed in summary in Table 5.

Table 5 shows the main insights and highlights the essential information for the development of the proposed framework.

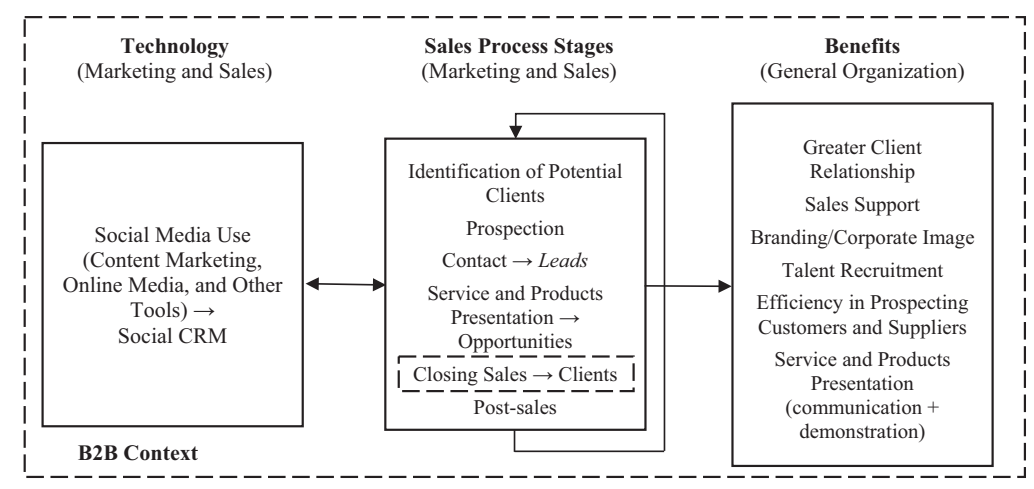

Source: The authors (2019)

Figure 1. Meta causal net 
RAUSP
56,1

16
Table 5.

Articles information for the Meta-

Synthesis

development

\section{|}

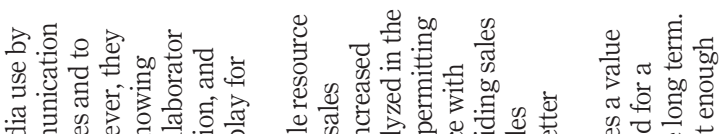

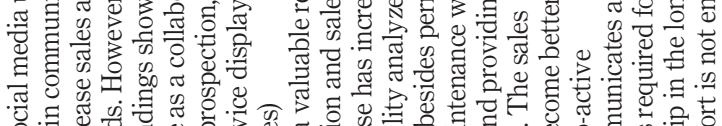

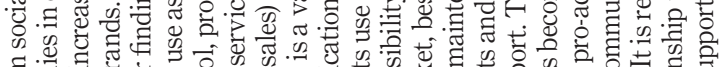

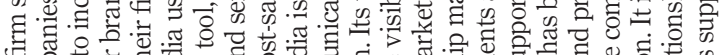

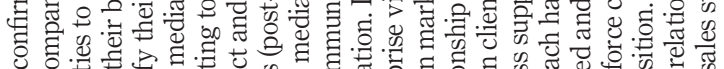

ठ

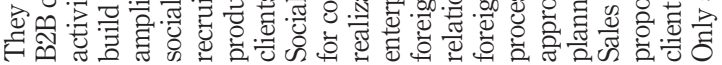

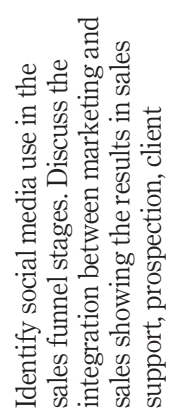

范

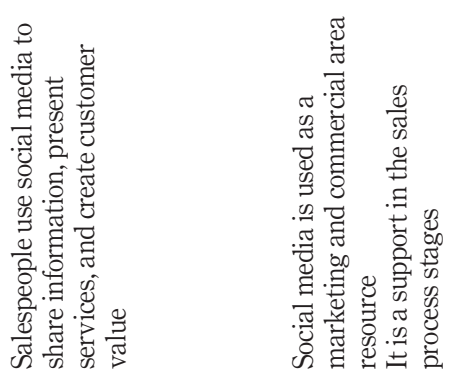

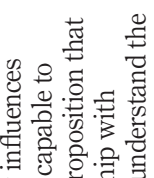

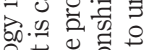

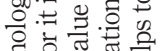

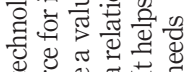

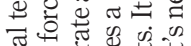

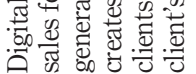

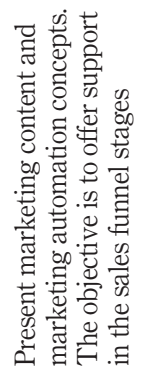

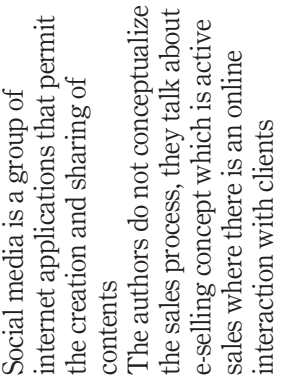

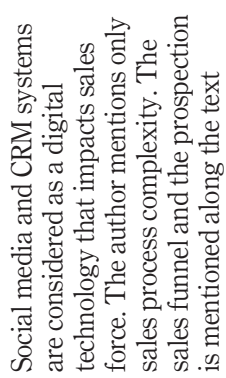

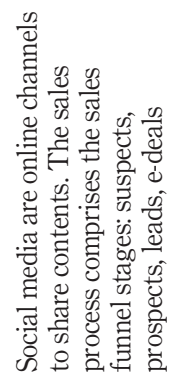

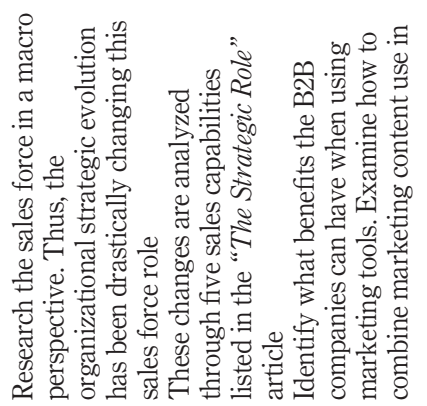

亗 $\frac{\sqrt{3}}{\sqrt[3]{2}}$

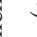



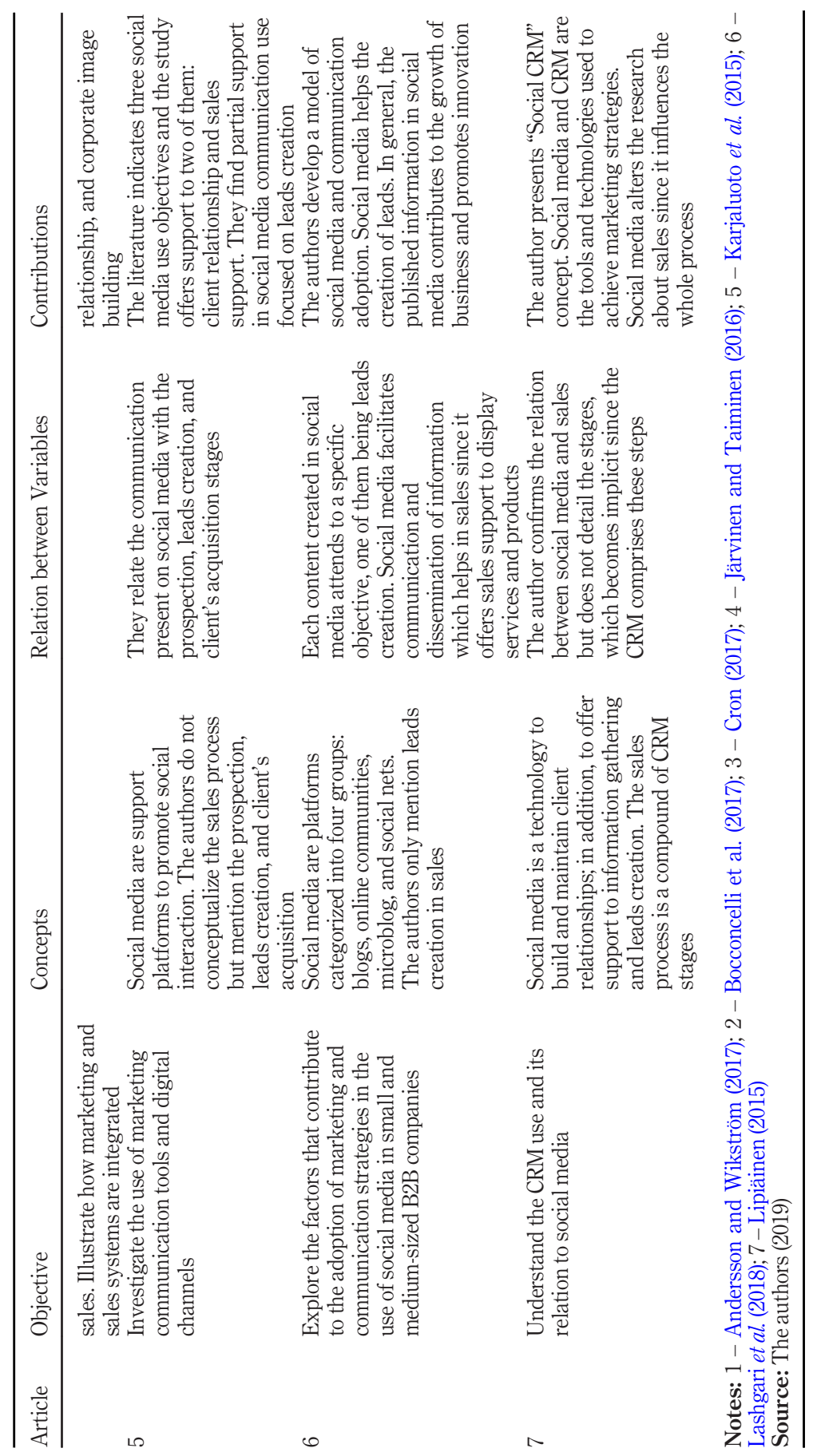

Use of social media 
RAUSP

56,1

Theory development from meta synthesis and results discussion

The studies of social media use and its relation to B2B negotiations offer a partial view about the theme. This meta-synthesis proposes a wide framework that embraces the main results in the research area using the case study method (Hoon, 2013).

From the articles that were analyzed, it is proposed that social media use is a tool that comprises as much the creation as the exchange of content by users (Kaplan \& Haenlein, 2010). The studies mentioned some of these tools, such as Facebook, Instagram and Youtube, as well as suggesting explanations about their use (Andersson \& Wikström, 2017; Bocconcelli et al., 2017; Järvinen \& Taiminen, 2016). Lipiäinen (2015) and Cron (2017) highlighted the CRM tool. Lipiäinen (2015) discussed the CRM social concept and showed the strong social media influence in the tools already used in the marketing area.

Järvinen \& Taiminen (2016) presented the requirement for greater integration between sales and marketing areas. The objective was the use of fewer resources for the leads qualification stage, leaving more options to apply in all sales processes. This integration resulted in a greater volume of qualified leads and resource optimization. Another benefit was the sales support; however, with resource optimization, there was a possibility of increased focus on the relationship between consumers and salespeople, which generated better results in the long-term (Andersson \& Wikström, 2017).

This integration between consumers and salespeople is benefited by better communication, which is only possible with greater agility in the process, knowledge about message monitoring and use of media and online tools (Bocconcelli et al., 2017; Karjaluoto et al., 2015). This justifies the requirement to propose a framework that shows the visualization of social media use and its impact on the sales process.

The discussion about the integration between sales and marketing areas in the use of social media in sales activities (Bocconcelli et al., 2017; Järvinen \& Taiminen, 2016; Karjaluoto et al., 2015) is relevant in the literature. Thus, it is proposed:

P1. Social media use should be performed by sales and marketing areas that enjoy the benefits of this integration.

In addition to social media and CRM, marketing automation, content marketing, e-mail use, and blogging, are tools found in studies (Andersson \& Wikström, 2017; Bocconcelli et al., 2017), but this does not prevent social media from being a post-sales tool or a prospection; however, more studies in the area are necessary. For these reasons, it was decided to study the use of social media as a whole and not specify each media. These media frequently change (Kaplan \& Haenlein, 2010) and it is as difficult to understand them as it is to identify qualified professionals to use them adequately (Andersson \& Wikström, 2017).

In addition to social media and CRM tools, marketing automation, content marketing, e-mail use and blogging, are found in studies (Andersson \& Wikström, 2017; Bocconcelli et al., 2017; Järvinen \& Taiminen, 2016; Karjaluoto et al., 2015; Lashgari et al., 2018; Lipiäinen, 2015). This fact reinforces the requirement to understand the importance of social media use and its influence, i.e. its logic of use and not the specific application of each media because they change constantly. The use in the sales process steps brings the companies benefits, including client relationship and sales support (Andersson \& Wikström, 2017; Bocconcelli et al., 2017; Karjaluoto et al., 2015; Lashgari et al., 2018; Lipiäinen, 2015), improved corporate image and branding (Andersson \& Wikström, 2017; Karjaluoto et al., 2015) and help in talent recruitment, prospection, service and product presentation (Andersson \& Wikström, 2017; Bocconcelli et al., 2017):

P2. The use of social media (content marketing, online media and other tools) in the sales process stages creates benefits to organizations such as better relationship 
with clients, sales support, improvement of the corporate image and brand, help with talent recruitment, enhanced prospection of clients and suppliers and services and products presentation.

There is consensus in the literature that social media use offers sales support; however, the inclusion of all stages in a single framework is a differential. Post-sales is a great application stage in the business accomplishment among companies because of its impact on client relationship and maintenance contact (Bocconcelli et al., 2017; Chang, 2014). For this reason, it must not be left out of the proposed model. Moreover, all the proposed stages demand tasks that can be done by sales and marketing, which are areas that must work together (Järvinen \& Taiminen, 2016; Karjaluoto et al., 2015). B2B sales process suffers social media use influence. After client contact is made, this process again influences social media because it promotes client interaction and engagement with the value proposal creation (Bocconcelli et al., 2017; Cron, 2017). Thus, a third proposition is presented:

P3a. Social media use influences sales processes, composed of the stages of identification of potential clients, prospection, contact with clients, service and products presentation, closing sales and post-sales.

$P 3 b$. Social media use is a mediator between the sales process stages and the benefits generated for the organization.

The interaction occurs all the time. The organization interacts with clients in social media and they provide information. Much more optimized content is published because of this constant exchange. The value is then co-created between the parties because both manifest themselves in the sales process (Lipiäinen, 2015). Cron (2017) emphasized that this interaction brings a value proposal. This joint work (social media in the B2B sales process) offers benefits to the companies such as improved customer assistance and content offerings adequate to the client's expectations.

There are three benefits consolidated in the literature and recurrently appearing in the analyzed articles (greater client relationships, sales support and corporate image/branding). This study has identified three other benefits and has added them to the proposed framework (Karjaluoto et al., 2015; Andersson \& Wikström, 2017; Bocconcelli et al., 2017).

Finally, the discussion about CRM social concept in a B2B context (Lipiäinen, 2015) reinforces social media relevance. Its use has been changing the way companies operate already consolidated tools such as CRM, thus modifying the business model, including B2B negotiations.

\section{Final considerations}

The general objective has been achieved because the building of a theoretical framework was obtained from data found in empirical studies according to the meta synthesis method (Hoon, 2013). Three theoretical contributions have been shown:

(1) social media use demands activities in the marketing and sales areas;

(2) social media use influences the sales process stages and brings a series of benefits to companies; and

(3) social media influences the sales process stages while acting as a mediator in the relation between these stages and the identified benefits.

Research about social media use and B2B sales processes are fragmented; the present study permitted a wide framework view. The qualitative case studies offered relevant information for developing this model and to verify repetitive information among studies. The relevance of these concepts to the problem proposed in the research has been demonstrated. The selected 
RAUSP

56,1

cases were published between 2015 and 2018, which shows the current importance of this theme. Conceptual study models were found, reinforcing the existence of opportunities for research and theory development. Comparisons among different studies are necessary to discuss and consolidate the concepts in the area while new studies can complement this study. Future research can test the proposed framework and increase the understanding of the consequences of social media use using large-, medium- and small-sized companies.

It is a consensus in the literature that social media use helps the relationship with clients, branding and sales support. However, its use extrapolates these points. According to Lipiäinen (2015) and Cron (2017), social media use is much more than a sales and support technology; it is an essential element in value co-creation. Future studies could advance the understanding of this interaction between business and clients in the creation of a value proposal (Cron, 2017), thus investigating and measuring client engagement during the sales process.

A limitation of this study is the number of studies using the case study method about the theme, only seven articles being analyzed. Despite the existence of but a few studies, they were published in high-impact journals, which shows the relevance of the analysis and its potential contribution to future studies.

\section{References}

Agnihotri, R., Dingus, R., Hu, M. Y., \& Krush, M. T. (2016). Social media: Influencing customer satisfaction in B2B sales. Industrial Marketing Management, 53, 172-180. https://doi.org/10.1016/j. indmarman.2015.09.003

Agnihotri, R., Kothandaraman, P., Kashyap, R., \& Singh, R. (2012). Bringing "social” into sales: the impact of salespeople's social media use on service behaviors and value creation. Journal of Personal Selling \& Sales Management, 32, 333-348. https://doi.org/10.2753/PSS0885-3134320304

Albers, S., Raman, K., \& Lee, N. (2015). Trends in optimization models of sales force management. Journal of Personal Selling \& Sales Management, 35, 275-291. https://doi.org/10.1080/ 08853134.2015.1085807

Andersson, S., \& Wikström, N. (2017). Why and how are social media used in a B2B context, and which stakeholders are involved?. Journal of Business \& Industrial Marketing, 32, 1098-1108. https:// doi.org/10.1108/JBIM-07-2016-0148

Andzulis, J. M., Panagopoulos, N. G., \& Rapp, A. (2012). A review of social media and implications for the sales process. Journal of Personal Selling \& Sales Management, 32, 305-316. https://doi.org/ 10.2753/PSS0885-3134320302

Annett-Hitchcock, K., \& Xu, Y. (2015). Shopping and virtual communities for consumers with physical disabilities. International Journal of Consumer Studies, 39, 136-144. https://doi.org/10.1111/ijcs.12161

Arriaga, J. L. D. O., Andreu Domingo, D., \& Berlanga Silvente, V. (2017). Facebook in the low-cost fashion sector: the case of primark. Journal of Fashion Marketing and Management: An International Journal, 21, 512-522. https://doi.org/10.1108/JFMM-08-2016-0069

Batra, R., \& Keller, K. L. (2016). Integrating marketing communications: New findings, new lessons, and new ideas. Journal of Marketing, 80, 122-145. https://doi.org/10.1509/jm.15.0419

Bocconcelli, R., Cioppi, M., \& Pagano, A. (2017). Social media as a resource in SMEs' sales process. Journal of Business \& Industrial Marketing, 32, 693-709. https://doi.org/10.1108/JBIM-11-2014-0244

Bohlin, E., Shaikh, A. A., \& Hanafizadeh, P. (2018). Social network banking: a case study of 100 leading global banks. International Journal of E-Business Research (Research), 14, 1-13. https://doi.org/ 10.4018/IJEBR.2018040101

Bolos, C., Idemudia, E. C., Mai, P., Rasinghani, M., \& Smith, S. (2016). Conceptual models on the effectiveness of e-marketing strategies in engaging consumers. Journal of International Technology and Information Management, 25, 3. 
Brink, T. (2017). B2B SME management of antecedents to the application of social media. Industrial Marketing Management, 64, 57-65. https://doi.org/10.1016/j.indmarman.2017.02.007

Chang, W. J. (2014). Market orientation and business-to-business (B2B): a Meta-analysis perspective. International Journal of Services Technology and Management, 20, 123-148. https://doi.org/ 10.1504/IJSTM.2014.063569

Chen, C., \& Gao, T. (2019). Sender outcomes of online word-of-mouth transmission. Journal of Consumer Marketing, 36, 197-205. https://doi.org/10.1108/JCM-11-2017-2452

Cron, W. L. (2017). Macro sales force research. Journal of Personal Selling \& Sales Management, 37, 188-197. https://doi.org/10.1080/08853134.2017.1352449

de Brito Silva, M. J., Santana, S. A., \& da Costa, M. F. (2018). How should I dress? understanding the clothing consumption of businesswomen in the clothing market. Revista Brasileira de Marketing, 17, 788-805.

D'Haen, J., \& Van den Poel, D. (2013). Model-supported business-to-business prospect prediction based on an iterative customer acquisition framework. Industrial Marketing Management, 42, 544-551. https://doi.org/10.1016/j.indmarman.2013.03.006

Dombrowski, U., \& Malorny, C. (2016). Process identification for customer service in the field of the after sales service as a basis for "lean after sales service. Procedia Cirp, 47, 246-251. https://doi. org/10.1016/j.procir.2016.03.030

Drechsler, A., \& Weißschädel, S. (2018). An IT strategy development framework for small and medium enterprises. Information Systems and e-Business Management, 16, 93-124. https://oi.org/ 10.1007/s10257-017-0342-2

Flaherty, K. E., Lassk, F., Lee, N., Marshall, G. W., Moncrief, W. C., Mulki, J. P., \& Pullins, E. B. (2018). Sales scholarship: Honoring the past and defining the future (key takeaways from the 2018 American Marketing Association faculty consortium: New horizons in selling and sales management). Journal of Personal Selling \& Sales Management, 38, 413-421. https:/doi.org/10.1080/08853134.2018.1537796

Garner, A., Goldberg, J., \& Pou, R. (2017). Collaborative social media campaigns and special collections: a case study on\# ColorOurCollections. RBM: A Journal of Rare Books, Manuscripts, and Cultural Heritage, 17 , https://doi.org/10.5860/rbm.17.2.9663

Gilfoil, D. M., Aukers, S. M., \& Jobs, C. G. (2015). Developing and implementing a social media program while optimizing return on investment - An MBA program case study. American Journal of Business Education (Ajbe), 8, 31-48. https://doi.org/10.19030/ajbe.v8i1.9015

Guenzi, P., Sajtos, L., \& Troilo, G. (2016). The dual mechanism of sales capabilities in influencing organizational performance. Journal of Business Research, 69, 3707-3713. https://doi.org/ 10.1016/j.jbusres.2016.03.033

Habibi, F., Hamilton, C. A., Valos, M. J., \& Callaghan, M. (2015). E-marketing orientation and social media implementation in B2B marketing. European Business Review, 27, 638-655. https://doi. org/10.1108/EBR-03-2015-0026

Hofacker, C. F., Malthouse, E. C., \& Sultan, F. (2016). Big data and consumer behavior: Imminent opportunities. Journal of Consumer Marketing, 33, 89-97. https://doi.org/10.1108/JCM-04-2015-1399

Hoon, C. (2013). Meta-synthesis of qualitative case studies: An approach to theory building. Organizational Research Methods, 16, 522-556. https://doi.org/10.1177/1094428113484969

Ioanid, A., Militaru, G., \& Mihai, P. (2015). Social media strategies for organizations using influencers' power. European Scientific Journal, ESJ, 11.

Itani, O. S., Agnihotri, R., \& Dingus, R. (2017). Social media use in B2b sales and its impact on competitive intelligence collection and adaptive selling: Examining the role of learning orientation as an enabler. Industrial Marketing Management, 66, 64-79. https://doi.org/10.1016/j.indmarman.2017.06.012

Järvinen, J., \& Taiminen, H. (2016). Harnessing marketing automation for B2B content marketing. Industrial Marketing Management, 54, 164-175. https://doi.org/10.1016/j. indmarman.2015.07.002

Jones, N., Borgman, R., \& Ulusoy, E. (2015). Impact of social media on small businesses. Journal of Small Business and Enterprise Development, 22, 611-632. https://doi.org/10.1108/JSBED-09-2013-0133 
RAUSP

56,1

Kaplan, A. M., \& Haenlein, M. (2010). Users of the world, unite! The challenges and opportunities of social media. Business Horizons, 53, 59-68. https://doi.org/10.1016/j.bushor.2009.09.003

Karjaluoto, H., Mustonen, N., \& Ulkuniemi, P. (2015). The role of digital channels in industrial marketing communications. Journal of Business \& Industrial Marketing, 30, 703-710. https://doi. org/10.1108/JBIM-04-2013-0092

Khang, H., Ki, E. J., \& Ye, L. (2012). Social media research in advertising, communication, marketing, and public relations, 1997-2010. Journalism \& Mass Communication Quarterly, 89, 279-298. https://doi.org/10.1177/1077699012439853

Kim, Y., Dwivedi, R., Zhang, J., \& Jeong, S. R. (2016). Competitive intelligence in social media twitter: iPhone 6 vs Online Information Review, 40, 42-61. https://doi.org/10.1108/OIR-03-2015-0068

Lashgari, M., Sutton-Brady, C., Solberg Søilen, K., \& Ulfvengren, P. (2018). Adoption strategies of social media in B2B firms: A multiple case study approach. Journal of Business \& Industrial Marketing, 33, 730-743. https://doi.org/10.1108/JBIM-10-2016-0242

Lin, H. C., Swarna, H., \& Bruning, P. F. (2017). Taking a global view on Brand post popularity: Six social media Brand post practices for global markets. Business Horizons, 60, 621-633. https:// doi.org/10.1016/j.bushor.2017.05.006

Lindsey-Mullikin, J., \& Borin, N. (2017). Why strategy is key for successful social media sales. Business Horizons, 60, 473-482. https://doi.org/10.1016/j.bushor.2017.03.005

Lipiäinen, H. S. M. (2015). CRM in the digital age: Implementation of CRM in three contemporary B2B firms. Journal of Systems and Information Technology, 17, 2-19. https://doi.org/10.1108/JSIT-06-2014-0044

Mahapatra, S., Ramani, A. T. P., \& Kulkarni, A. D. (2019). Must have or nice to have. Journal of Business \& Industrial Marketing, 34, 39-48. https://doi.org/10.1108/JBIM-09-2017-0209

Marolt, M., Pucihar, A., \& Zimmermann, H. D. (2015). Social CRM adoption and its impact on performance outcomes: A literature review. Organizacija, 48, 260-271. https://doi.org/10.1515/orga-2015-0022

Marshall, G. W., Moncrief, W. C., Rudd, J. M., \& Lee, N. (2012). Revolution in sales: The impact of social media and related technology on the selling environment. Journal of Personal Selling \& Sales Management, 32, 349-363. https://doi.org/10.2753/PSS0885-3134320305

Mauroner, O. (2016). Social media for the purpose of knowledge creation and creativity management A study of knowledge workers in Germany. International Journal of Learning and Intellectual Capital, 13, 167-183. https://doi.org/10.1504/IJLIC.2016.075694

Mirza, M. S. (2014). A report on information dissemination strategies: The case of da'wah academy. Journal of Religious \& Theological Information, 13, 111-118. https://doi.org/10.1080/ 10477845.2014.963477

Moncrief, W. C. (2017). Are sales as we know it dying. . . or merely transforming. ? Journal of Personal Selling \& Sales Management, 37, 271-279. https://doi.org/10.1080/08853134.2017.1386110

Moncrief, W. C., Marshall, G. W., \& Rudd, J. M. (2015). Social media and related technology: Drivers of change in managing the contemporary sales force. Business Horizons, 58, 45-55. https://doi.org/ 10.1016/j.bushor.2014.09.009

Ngai, E. W., Moon, K. L. K., Lam, S. S., Chin, E. S., \& Tao, S. S. (2015). Social media models, technologies, and applications: An academic review and case study. Industrial Management \& Data Systems, 115, 769-802. https://doi.org/10.1108/IMDS-03-2015-0075

Nicoli, N., \& Papadopoulou, E. (2017). TripAdvisor and reputation: A case study of the hotel industry in Cyprus. EuroMed Journal of Business, 12, 316-334. https://doi.org/10.1108/EMJB-11-2016-0031

Nunan, D., Sibai, O., Schivinski, B., \& Christodoulides, G. (2018). Reflections on "social media: Influencing customer satisfaction in B2B sales" and a research agenda. Industrial Marketing Management, 75, 31-36. https://doi.org/10.1016/j.indmarman.2018.03.009

Oh, J. H. (2017). A conceptual framework for successful salesperson role change management. Journal of Business \& Industrial Marketing, 32, 1136-1143. https://doi.org/10.1108/JBIM-07-2016-0163 
Orozco, D. (2016). Using social media in business disputes. MIT Sloan Management Review, 57, 33.

Papp-Vary, A. (2015). Indicators and methodologies for the assessment of product placement. Journal of Media Research-Revista de Studii Media 8, 27-40.

Rane, D., Mulla, N. A., Sarguru, D., \& Sayed, S. (2017). Sales performance management system. International Journal of Computer Applications, 162, 162. https://doi.org/10.5120/ijca2017913404

Rapp, A., Beitelspacher, L. S., Grewal, D., \& Hughes, D. E. (2013). Understanding social media effects across seller, retailer, and consumer interactions. Journal of the Academy of Marketing Science, 41, 547-566. https://doi.org/10.1007/s11747-013-0326-9

Roch, J., \& Mosconi, E. (2016). The use of social media tools in the product life cycle phases: A systematic literature review. 49th HI International Conference on System Sciences (HICSS), IEEE, pp. 1830-1839, https://doi.org/10.1109/HICSS.2016.232

Rodriguez, M., Ajjan, H., \& Peterson, R. M. (2016). Social media in large sales forces: An empirical study of the impact of sales process capability and relationship performance. Journal of Marketing Theory and Practice, 24, 365-379. https://doi.org/10.1080/10696679.2016.1170538

Rodriguez, M., Peterson, R. M., \& Krishnan, V. (2012). Social media's influence on business-to-business sales performance. Journal of Personal Selling \& Sales Management, 32, 365-378. https://doi.org/ 10.2753/PSS0885-3134320306

Sanakulov, N., Kalliomaa, S., \& Karjaluoto, H. (2018). Salesperson adoption and usage of mobile sales configuration tools. Journal of Systems and Information Technology, 20, 168-190. https://doi.org/ 10.1108/JSIT-09-2017-0073

Shemi, A. P., \& Procter, C. (2018). E-commerce and entrepreneurship in SMEs: Case of myBot. Journal of Small Business and Enterprise Development, 25, 501-520. https://doi.org/10.1108/JSBED-03-2017-0088

Siamagka, N. T., Christodoulides, G., Michaelidou, N., \& Valvi, A. (2015). Determinants of social media adoption by B2B organizations. Industrial Marketing Management, 51, 89-99. https://doi.org/ 10.1016/j.indmarman.2015.05.005

Spragg, J. E. (2017). Articulating the fashion product life-cycle. Journal of Fashion Marketing and Management: An International Journal, 21, 499-511. https://doi.org/10.1108/JFMM-03-2017-0029

Thorat, S., Deshpande, P., \& Shaga, V. (2017). Review of sentiment analysis on twitter data using Python. International Journal of Advanced Research in Computer Science, 8. https://doi.org/ 10.26483/ijarcs.v8i9.4956

Trainor, K. J., Andzulis, J. M., Rapp, A., \& Agnihotri, R. (2014). Social media technology usage and customer relationship performance: A capabilities-based examination of social CRM. Journal of Business Research, 67, 1201-1208. https://doi.org/10.1016/j.jbusres.2013.05.002

Valos, M. J., Haji Habibi, F., Casidy, R., Driesener, C. B., \& Maplestone, V. L. (2016). Exploring the integration of social media within integrated marketing communication frameworks: Perspectives of services marketers. Marketing Intelligence \& Planning, 34, 19-40. https://doi.org/10.1108/MIP-09-2014-0169

Zhao, Z., \& Balagué, C. (2015). Designing branded mobile apps: Fundamentals and recommendations. Business Horizons, 58, 305-315. https://doi.org/10.1016/j.bushor.2015.01.004

\section{Corresponding author}

Graziela Perretto Rodrigues can be contacted at: grazielarodrigues@gmail.com

Associate Editor: Filipe Quevedo-Silva

For instructions on how to order reprints of this article, please visit our website:

www.emeraldgrouppublishing.com/licensing/reprints.htm

Or contact us for further details: permissions@emeraldinsight.com 